Available online at https://jurnal.stmikroyal.ac.id/index.php/jurdimas

\title{
PEMBEKALAN EXPLAINER VIDEO BAGI SISWA DALAM MENGHADAPI ERA REVOLUSI INDUSTRI 4.0
}

\author{
Handoko $^{1^{*}}$, Angela ${ }^{1}$, Gunawan ${ }^{2}$ \\ ${ }^{1}$ Program Studi Sistem Informasi, STMIK Mikroskil \\ ${ }^{2}$ Program Studi Teknik Informatika, STMIK Mikroskil \\ email: *handoko.wu@mikroskil.ac.id
}

\begin{abstract}
The 4.0 Industrial Revolution is marked by rapid advances and technological changes in various fields, including education. To welcome the era of the 4.0 Industrial Revolution, learning curriculum in schools must follow the technological advancement. Teachers generally provide group assignments to be presented by students. The main obstacle faced is that students are less capable to create and deliver presentation content. Therefore, it is necessary to provide insight about presentation ability and the use of technology to make presentations. The activity began by compiling a training module on using Explaindio Video Creator to make explainer video. Training is provided in the form of tutorials and workshops, so students can directly practice the material being discussed. Before and after the training, pre-test and post-test was conducted to test the students' understanding of the presentation using an explainer video. The results found that the average participants before attending this training did not understand the presentation technique and did not know about the presentation assisted by explainer video. After attending the training, the average participants have already understood the presentation techniques and already known about the presentation assisted by explainer video and made it on their own.
\end{abstract}

Keywords: explainer video; industrial revolution; presentation

\begin{abstract}
Abstrak: Revolusi Industri 4.0 ditandai dengan kemajuan dan perubahan teknologi yang pesat di berbagai bidang, tidak terkecuali bidang pendidikan. Untuk menyongsong era Revolusi Industri 4.0, kurikulum pembelajaran di sekolah harus mengikuti kemajuan teknologi. Guru mata pelajaran umumnya memberikan tugas kelompok untuk dipresentasikan oleh siswa-siswi. Kendala utama yang dihadapi adalah siswa-siswi kurang mampu membuat dan menyampaikan konten presentasi. Karena itu, perlu adanya pemberian wawasan terkait kemampuan presentasi dan pemanfaatan teknologi untuk melakukan presentasi. Kegiatan dimulai dengan menyusun modul pelatihan mengenai penggunaan Explaindio Video Creator untuk mengembangkan explainer video. Pelatihan diberikan dalam bentuk tutorial dan workshop, sehingga siswa-siswi bisa mempraktikkan secara langsung materi yang dibahas. Sebelum dan sesudah pelatihan, dilakukan pre-test dan post-test untuk menguji pemahaman siswa-siswi terkait presentasi dengan menggunakan explainer video. Hasilnya ditemukan bahwa rata-rata peserta sebelum mengikuti pelatihan ini belum memahami tentang teknik presentasi serta belum mengetahui tentang bantuan presentasi dengan menggunakan explainer video. Setelah mengikuti pelatihan, rata-rata peserta sudah dapat memahami tentang teknik presentasi serta sudah mengetahui tentang bantuan presentasi dengan menggunakan explainer video dan sudah dapat membuatnya.
\end{abstract}

Kata kunci: explainer video; presentasi; revolusi industri 
Available online at https://jurnal.stmikroyal.ac.id/index.php/jurdimas

\section{PENDAHULUAN}

Setiap revolusi industri telah mengubah cara hidup, bekerja, dan berinteraksi satu sama lain. Revolusi industri pertama memperkenalkan mesin uap sebagai alat produksi. Pada revolusi industri kedua, tenaga listrik digunakan untuk produksi massal. Kemudian, pada revolusi industri ketiga, elektronik dan teknologi informasi dimanfaatkan untuk melakukan otomasi pada proses produksi. Lalu, revolusi industri keempat merupakan perkembangan dari revolusi industri ketiga dimana pada Revolusi Industri 4.0 ini perkembangan teknologi sangat pesat sampai mengaburkan batas-batas antara dunia fisik, digital, dan biologis (Schwab, 2016).

Revolusi Industri 4.0 ditandai oleh kemajuan dan perubahan yang sangat cepat dalam teknologi baru, seperti Internet of Things (IoT), kendaraan self-driving, nanoteknologi, energi terbarukan, komputasi kuantum, dan bioteknologi. Revolusi Industri 4.0 tidak hanya memengaruhi bisnis, pemerintah, dan masyarakat, tetapi juga bidang pendidikan, dimana terdapat model baru pendidikan untuk masa depan sehingga memunculkan pula istilah $E d u$ cation 4.0 (Hussin, 2018; Shahroom \& Hussin, 2018). Dalam Revolusi Industri 4.0, kurikulum pembelajaran di sekolah harus mengacu pada teknologi informasi, IoT, big data, dan komputer (Lase, 2019). Adapun salah satu sekolah yang ingin membekali siswanya untuk menghadapi revolusi industri ini adalah SMA Tri Ratna Sibolga.

SMA Tri Ratna Sibolga terletak di Jalan Letjen. S. Parman Pasar Belakang, Kota Sibolga dan merupakan sekolah berciri khas Buddhis yang mengutamakan kualitas yang bermutu dan berdaya saing tinggi serta mencerminkan
Buddha Dharma. Siswa-siswi SMA Tri Ratna Sibolga memperoleh berbagai mata pelajaran di sekolah untuk meningkatkan pengetahuan dan wawasan. Pada beberapa mata pelajaran, guru biasanya memberikan tugas kelompok untuk dikerjakan siswa-siswi. Setelah itu, siswa-siswi akan diminta untuk mempresentasikan hasilnya. Jika semua kelompok harus mempresentasikan hasilnya, maka akan dibutuhkan waktu yang cukup lama. Selain itu, untuk menjelaskan satu hal membutuhkan waktu yang lama, padahal banyak hal yang harus dibahas. Atau ada hal-hal tertentu yang susah dijelaskan dengan menggunakan kata-kata, akibatnya guru yang akan memberikan penilaian dan siswa-siswi lain yang mendengarkan presentasi malah kebingungan dengan apa yang disampaikan.

Usia anak-anak SMA sekarang termasuk dalam generasi $\mathrm{Z}$ yang sangat familiar dengan teknologi. Mereka memiliki preferensi belajar yang berbeda dibandingkan siswa-siswi generasi pendahulunya, dimana siswa-siswi Gen Z lebih suka belajar dan terlibat langsung dalam segi praktikal. Selain itu, karena dibesarkan pada era digital, siswa-siswi tersebut senang dan berharap bahwa teknologi digital selalu tersedia untuk digunakan. Oleh karena itu, siswa-siswi Gen $\mathrm{Z}$ ini perlu dipersiapkan untuk menghadapi era Revolusi Industri 4.0 (Hussin, 2018).

Berdasarkan survei terhadap para kepala sumber daya manusia perusahaan terkemuka dunia, World Economic Forum telah merilis laporan yang mengungkapkan 10 (sepuluh) keterampilan teratas yang dibutuhkan pada tahun 2020, dimana salah satunya adalah keterampilan "Negosiasi dan Presentasi" (Gray, 2016). Untuk mendukung karir siswa-siswi di masa depan, dibutuhkan 
Available online at https://jurnal.stmikroyal.ac.id/index.php/jurdimas

kreativitas, pemikiran kritis, keterampilan interpersonal, kemampuan menulis, keterampilan presentasi, dan negosiasi. Keterampilan membuat dan menyajikan argumen, mengajukan pertanyaan yang tepat dan mencari jawabannya adalah keterampilan yang harus diajarkan bersama dengan keterampilan teknis lainnya ke siswa-siswi sejak dini (Gleason, 2018). Kemampuan presentasi yang baik mencakup banyak aspek komunikasi, baik yang terencana maupun tidak sehingga sulit untuk dikuasai (Rafidiyah \& Thania, 2018).

Presentasi adalah kegiatan berbicara di depan masyarakat/khalayak ramai (audiens) dalam rangka mengajukan suatu ide atau gagasan untuk mendapatkan pemahaman atau kesepakatan bersama. Kemampuan presentasi wajib dimiliki anak muda yang berdaya saing tinggi. Salah satu cara yang paling sering digunakan untuk mengasah kemampuan ini sejak bangku sekolah adalah mempresentasikan tugas. Pada saat di perkuliahan, biasanya presentasi menjadi sesuatu yang wajib dikuasai. Kemampuan berbicara, bernegosiasi, dan meyakinkan orang dalam aspek pekerjaan untuk mengadakan kesepakatan akan membuahkan hasil yang diharapkan. Kemampuan dalam menyampaikan ide-ide brilian dan masukan ketika presentasi juga sangat penting (Hanifa \& Yusra, 2018).

Kemampuan presentasi yang bagus bukanlah kemampuan yang hanya dimiliki segelintir orang. Semua orang dapat membawakan presentasi yang baik jika mempelajari bagaimana caranya. Untuk mendukung presentasi, dapat dipersiapkan slide presentasi yang berperan dalam penyampaian isi materi. Selain dikemas dengan lebih singkat dan menarik, slide dapat menjadi fasilitas untuk memaparkan hasil penelitian.
Kepaduan slide akan mendukung kelancaraan presentasi dan menarik perhatian audien, karena jika tidak adanya dukungan dari audien dapat mengganggu kelancaran dalam presentasi. Masalah lain yang dihadapi oleh presenter adalah rasa gugup berlebihan dan kekhawatiran terkait batas waktu presentasi (Hanifa \& Yusra, 2018). Dengan kemudahan teknologi yang ada saat ini, salah satu hal yang bisa dilakukan untuk mendukung presentasi adalah membuat explainer video (Laaser \& Toloza, 2017).

Explainer video dapat digambarkan sebagai video yang durasinya relatif singkat dan informatif (Ivanova, 2017). Explainer video biasanya menggabungkan skrip yang menarik, seperti animasi, teks, foto, gambar, musik, maupun media lain yang menghibur. Explainer video mampu secara efektif menyampaikan fakta kompleks kepada target penonton dalam waktu singkat, biasanya antara 1 s.d. 3 menit. Fokusnya bukan kepada hal-hal detil, tetapi lebih fokus pada fakta yang paling relevan (Krämer \& Böhrs, 2017). Selain itu, explainer video juga bisa diselipkan berbagai konten lucu dan cerita menarik dari perspektif siswa-siswi sehingga bisa membuat penonton betah (Bakri, Rodhiyah, Nurindrasari, Pratiwi, \& Muliyati, 2020). Saat ini, sudah banyak tools yang tersedia secara gratis untuk membuat explainer video, seperti Explaindio Video Creator. Dengan ada-nya pelatihan ini, diharapkan siswa-siswi SMA Tri Ratna Sibolga memiliki pemahaman dan pengetahuan dasar mengenai teknik presentasi yang baik serta mampu untuk menggunakan teknologi dalam membuat dan menyampaikan konten presentasi, khususnya dengan explainer video, sehingga mampu bersaing di era Revolusi Industri 4.0. 
Available online at https://jurnal.stmikroyal.ac.id/index.php/jurdimas

\section{METODE}

Kegiatan pelatihan dilakukan sebanyak 2 (dua) hari, diselenggarakan di laboratorium komputer SMA Tri Ratna Sibolga. Jumlah peserta pelatihan adalah sekitar 32 orang siswa-siswi SMA. Kegiatan pengabdian kepada masyarakat ini meliputi 3 (tiga) tahapan kegiatan, yakni:

Persiapan: mempersiapkan modul pelatihan dan mengembangkan contoh video presentasi yang akan dijadikan sebagai studi kasus pada saat pelaksanaan pelatihan. Contoh video presentasi dibuat dengan bantuan Explaindio Video Creator. Explaindio Video Creator merupakan aplikasi pengeditan video yang mudah digunakan dan lengkap untuk membuat animasi dasar, doodle sketch, dan motion video. Dari fungsinya, Explaindio Video Creator ini lebih condong digunakan bagi pengguna yang ingin membuat sebuah video presentasi atau video promosi yang menarik dengan mudah. Antarmuka aplikasi Explaindio Video Creator ini cukup sederhana sehingga mudah digunakan oleh pengguna pemula sekalipun. Jika dibandingkan dengan aplikasi sejenis lainnya, seperti Sparkol VideoScribe, aplikasi Explaindio Video Creator memiliki fitur yang lebih lengkap.

Pelaksanaan: pelaksanaan kegiatan pelatihan adalah selama 2 (dua) hari yang ditujukan kepada siswa-siswi kelas XII IPA SMA Tri Ratna Sibolga serta dilaksanakan di laboratorium komputer sekolah mitra. Awalnya, tim pengabdian akan memeriksa spesifikasi dan kelayakan komputer yang akan digunakan untuk instalasi aplikasi serta mempersiapkan berbagai dokumen (absensi/daftar hadir, modul pelatihan, kuesioner). Sebelum kegiatan pelatihan dimulai, siswa-siswi diminta untuk mengisi daftar hadir dan diberikan kuesioner pre-test untuk mengetahui sejauh apa pemahaman siswa-siswi terkait materi. Kemudian tim pengabdian akan memaparkan materi terkait pengenalan revolusi industri dan teknik presentasi yang baik. Siswa-siswi akan diajak untuk mempraktikkan langsung langkahlangkah pembuatan explainer video. Setelah siswa-siswi memahami cara penggunaannya, maka siswa-siswi diminta untuk membentuk kelompok dan membuat sendiri explainer video terkait topik yang menarik minat siswa-siswi. Siswa-siswi kemudian menunjukkan hasil kerjanya untuk dinilai dan diberikan masukan oleh tim pengabdian. Di akhir pelatihan, siswa-siswi diminta kembali untuk mengisi kuesioner post-test untuk mengetahui sejauh mana perkembangan kemampuan mahasiswa setelah selesai mengikuti pelatihan.

Evaluasi: Hasil kuesioner pre-test dan post-test yang diisi siswa-siswi yang mengikuti pelatihan akan dibandingkan dan dievaluasi untuk melihat kemampuan siswa-siswi sebelum dan setelah kegiatan pelatihan dilakukan. Pada kuesioner yang dikumpulkan, siswa-siswi juga memberikan saran dan masukan sehingga dapat dijadikan sebagai bahan review bagi tim pengabdian untuk pelaksanaan pelatihan berikutnya, baik dari segi isi materi, cara pembawaan, maupun pembagian waktu kegiatan pelatihan.

\section{PEMBAHASAN}

Pelatihan diberikan dalam bentuk tutorial dan workshop, dimana siswasiswi mempraktikkan secara langsung materi yang dibahas berdasarkan modul pelatihan yang disusun. Hari pertama kegiatan dimulai dari pukul 09.00 dan berakhir pada pukul 17.00 WIB. Kegiatan yang dilakukan meliputi absen- 
Available online at https://jurnal.stmikroyal.ac.id/index.php/jurdimas

si/registrasi peserta dan dilanjutkan dengan kuesioner pre-test untuk menguji pemahaman siswa-siswi terkait presentasi dengan menggunakan explainer video.

Adapun item pertanyaan pada kuesioner pre-test dapat dilihat pada Gambar 1. Selanjutnya dilakukan pengajaran materi mengenai Revolusi Industri 4.0, Teknik Presentasi, serta Explainer Video dan Langkah-Langkah Membuat Explainer Video dengan menggunakan Explaindio Video Creator. Sepanjang kegiatan pelatihan, peserta diberikan kesempatan untuk mempraktikkan secara langsung penggunaan Explaindio Video Creator untuk mengembangkan video presentasi pendek. Hari kedua pelaksanaan pelatihan juga dimulai dari pukul 09.00 dan berakhir pada pukul 17.00 WIB. Pada hari kedua pelaksanaan kegiatan pelatihan, sepenuhnya adalah kegiatan praktik karena materi pelatihan lebih berhubungan dengan kegiatan penggunaan Explaindio Video Creator.

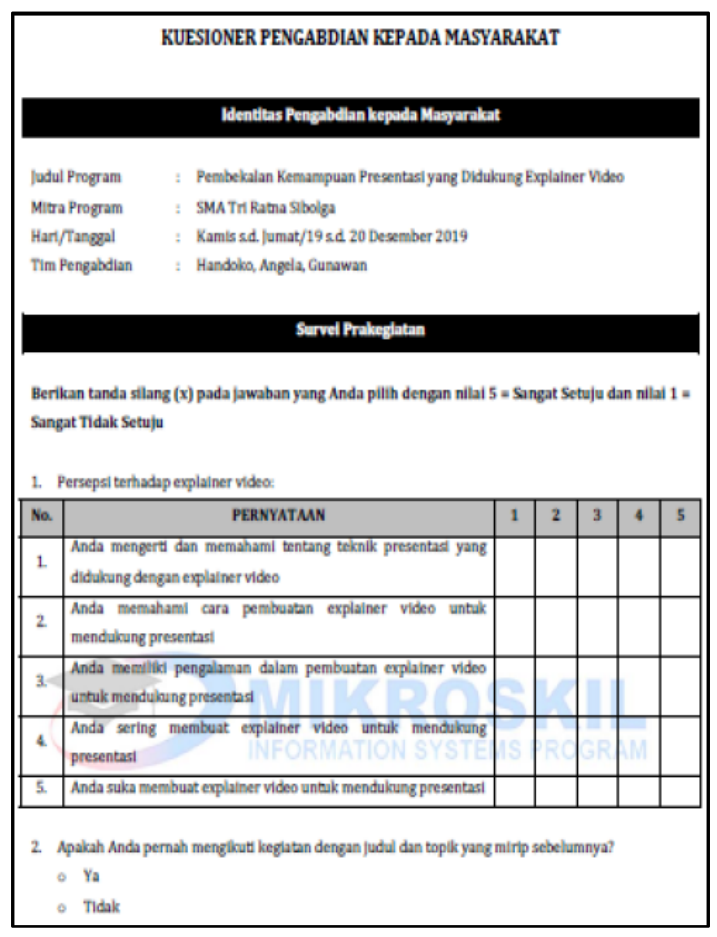

Gambar 1. Kuesioner Pre-test

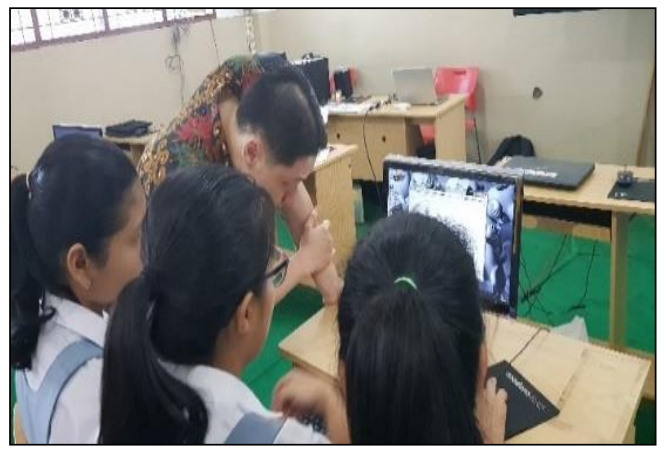

Gambar 2. Pendampingan Pelatihan

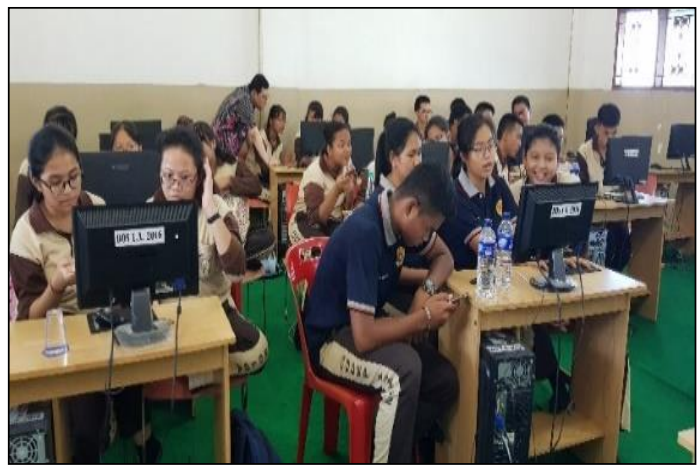

Gambar 3. Suasana Latihan Studi Kasus dan Test

Selain kegiatan pengajaran materi, di akhir pelaksanaan kegiatan hari kedua juga diberikan latihan studi kasus dan test untuk menguji sejauh mana pemahaman siswa-siswi terhadap materi yang sudah disampaikan di hari pertama dan kedua, dimana pengerjaan latihan studi kasus dan test-nya adalah per kelompok. Setiap kelompok juga diminta untuk membuat explainer video berdurasi maksimal 3 (tiga) menit untuk menjelaskan topik yang boleh dipilih sendiri oleh anggota kelompok dan kemudian dinilai.

Tim pengabdian selanjutnya akan memilih tiga kelompok dengan pembuatan video presentasi terbaik dan akan diberikan souvenir. Kriteria penilaiannya adalah berdasarkan seberapa menarik video presentasi yang dibuat serta seberapa baik video tersebut bisa menyampaikan isi topik yang disampaikan kepada penonton. 
Available online at https://jurnal.stmikroyal.ac.id/index.php/jurdimas

Pada akhir pelatihan, peserta pelatihan dibagikan kuesioner post-test sebagai media untuk menguji pemahaman siswa-siswi setelah mengikuti pelatihan dan bagi peserta untuk memberikan umpan balik atau respon sebagai bentuk tanggapan terhadap hasil pelaksanaan kegiatan pelatihan.

Adapun item pertanyaan kuesioner post-test dapat dilihat pada Gambar 4. Dari hasil rekapitulasi kuesioner pre-test, diketahui bahwa rata-rata siswa-siswi SMA Tri Ratna Sibolga belum memahami cara presentasi yang baik dan cara menggunakan explainer video untuk presentasi. Hal ini terlihat dari rata-rata jawaban yang didominasi di angka 1 sampai 3. Siswa-siswi juga sebagian besar belum pernah mengikuti kegiatan pelatihan terkait presentasi dengan $e x$ plainer video.

Setelah mengikuti pelatihan, ratarata siswa-siswi menjawab bahwa mereka telah mampu memahami teknik presentasi dan langkah-langkah membuat explainer video untuk mendukung presentasi mereka. Hal ini terlihat dari rata-rata jawaban yang didominasi angka 3 sampai 5. Meskipun demikian, ada sekitar 38,5\% siswa-siswi yang menyatakan bahwa waktu yang disediakan untuk kegiatan pelatihan masih tidak cukup sehingga perlu dipertimbangkan untuk mengatur kembali waktu pelatihan ke depannya.

Dari perbandingan hasil kuesioner pre-test dan post-test yang ditunjukkan pada Tabel 1 dan Tabel 2, dapat disimpulkan bahwa rata-rata peserta sebelum mengikuti pelatihan ini belum memahami tentang teknik presentasi serta belum mengetahui tentang bantuan presentasi dengan menggunakan explainer video. Setelah mengikuti pelatihan, rata-rata peserta sudah dapat memahami tentang teknik presentasi serta sudah mengetahui tentang bantuan presentasi dengan menggunakan explainer video dan sudah dapat membuatnya.

Semua peserta mengerti tujuan dari pelatihan ini. Dari sisi bahan pelatihan, semua peserta sepakat bahwa materi pelatihan dan perangkat presentasi mudah dipahami. Walaupun tujuan pelatihan tercapai dan bahan pelatihan memadai, namun rata-rata peserta menghendaki supaya durasi pelatihan bisa lebih panjang untuk mendukung pemahaman mereka terhadap materi pelatihan.

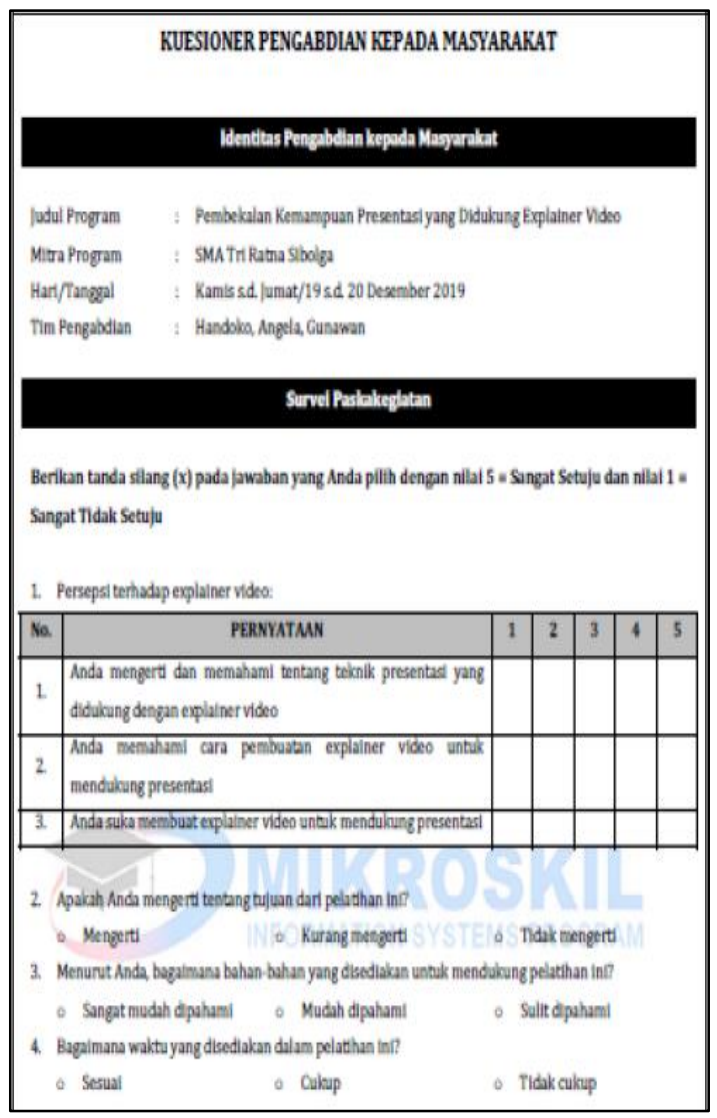

Gambar 4. Kuesioner Pre-test 
Available online at https://jurnal.stmikroyal.ac.id/index.php/jurdimas

Tabel 1. Rekapitulasi Hasil Review Kegiatan Pelatihan (Pre-Test)

\begin{tabular}{cccccc}
\hline & \multicolumn{5}{c}{ Kriteria Penilaian } \\
\cline { 2 - 6 } & $\mathbf{1}$ & $\mathbf{2}$ & $\mathbf{3}$ & $\mathbf{4}$ & $\mathbf{5}$ \\
\hline $\mathbf{1}$ & $0.0 \%$ & $36.7 \%$ & $\mathbf{4 6 . 7 \%}$ & $10.0 \%$ & $6.7 \%$ \\
\hline $\mathbf{2}$ & $23.3 \%$ & $26.7 \%$ & $\mathbf{3 3 . 3 \%}$ & $10.0 \%$ & $6.7 \%$ \\
\hline $\mathbf{3}$ & $30.0 \%$ & $16.7 \%$ & $\mathbf{3 3 . 3 \%}$ & $13.3 \%$ & $6.7 \%$ \\
\hline $\mathbf{4}$ & $30.0 \%$ & $\mathbf{4 3 . 3 \%}$ & $16.7 \%$ & $3.3 \%$ & $6.7 \%$ \\
\hline $\mathbf{5}$ & $10.0 \%$ & $26.7 \%$ & $\mathbf{4 6 . 7 \%}$ & $6.7 \%$ & $10.0 \%$ \\
\hline $\mathbf{6}$ & \multicolumn{5}{c}{ Ya: $10 \%$, Tidak: $\mathbf{9 0 \%}$} \\
\hline
\end{tabular}

Tabel 2. Rekapitulasi Hasil Review Kegiatan Pelatihan (Post-Test)

\begin{tabular}{lccccc}
\hline \multicolumn{5}{c}{ Kriteria Penilaian } \\
\cline { 2 - 6 } & $\mathbf{1}$ & $\mathbf{2}$ & $\mathbf{3}$ & $\mathbf{4}$ & $\mathbf{5}$ \\
\hline $\mathbf{1}$ & $0.0 \%$ & $0.0 \%$ & $23.1 \%$ & $\mathbf{5 0 . 0 \%}$ & $26.9 \%$ \\
\hline $\mathbf{2}$ & $0.0 \%$ & $0.0 \%$ & $19.2 \%$ & $\mathbf{5 3 . 9 \%}$ & $26.9 \%$ \\
\hline $\mathbf{3}$ & $0.0 \%$ & $0.0 \%$ & $\mathbf{3 4 . 6 \%}$ & $\mathbf{3 4 . 6 \%}$ & $30.8 \%$ \\
\hline $\mathbf{4}$ & \multicolumn{5}{c}{ Mengerti: 100\%, Kurang Mengerti: 0\%, Tidak Mengerti: $0 \%$} \\
\hline $\mathbf{5}$ & \multicolumn{5}{c}{ Sangat Mudah Dipahami: $0 \%$, Mudah Dipahami: $\mathbf{1 0 0 \%}$, Sulit Dipahami: $0 \%$} \\
\hline $\mathbf{6}$ & \multicolumn{5}{c}{ Sesuai: $19.2 \%$, Cukup: $\mathbf{4 2 . 3 \%}$, Tidak Cukup: $38.5 \%$} \\
\hline
\end{tabular}

\section{SIMPULAN}

Kegiatan pengabdian pada masyarakat berupa pelatihan pembuatan explainer video dengan menggunakan Explaindio Video Creator ini sangat tepat dilakukan untuk mendukung kemampuan presentasi siswa-siswi, mengingat kemampuan presentasi ini dapat menjadi bekal siswa-siswi ke depannya dalam menghadapi kerasnya persaingan di era Revolusi Industri 4.0.

Dalam pelaksanaan kegiatan, sebagian besar peserta dapat merasakan manfaatnya, sehingga melalui pemaparan yang sudah dijelaskan sebelumnya, pelaksanaan kegiatan pelatihan ini dapat dikategorikan berhasil. Siswa-siswi SMA Tri Ratna Sibolga telah mampu memahami konsep presentasi dan mengimplementasikan keterampilan tersebut dalam bentuk membuat sendiri explainer video. Meskipun demikian, perlu adanya pertimbangan penambahan durasi waktu apabila kegiatan pelatihan serupa akan diadakan kembali di waktu mendatang mengingat waktu yang disediakan dirasa kurang mencukupi.

\section{DAFTAR PUSTAKA}

Bakri, F., Rodhiyah, A., Nurindrasari, M., Pratiwi, S., \& Muliyati, D. (2020). The Design of Physics Learning Video as Joyful-Based Learning Media Enrichment by Powtoon. Journal of Physics: Conference Series 1491, 1-5.

Gleason, N. W. (2018). Higher Education in the Era of the Fourth Industrial Revolution. Springer Nature.

Gray, A. (2016). The 10 skills you need to thrive in the Fourth Industrial Revolution. Retrieved June 12, 2020, from World Economic Forum: 
https://www.weforum.org/agenda/ 2016/01/the-10-skills-you-needto-thrive-in-the-fourth-industrialrevolution/

Hanifa, R., \& Yusra, S. R. (2018). Insight on Delivering Oral Presentation: Preparations, Problems, and Solutions. International Journal of Learning and Teaching, 4(4), 318-325.

Hussin, A. A. (2018). Education 4.0 Made Simple: Ideas For Teaching. International Journal of Education \& Literacy Studies, 6(3), 92-98.

Ivanova, S. (2017). Using Explainer Videos To Teach Web Design Concepts. Conference proceedings of eLearning and Software for Education. Vol. 1, No. 1, pp. 429-434. Carol I National Defence University Publishing House.

Krämer, A., \& Böhrs, S. (2017). How Do Consumers Evaluate Explainer Videos? An Empirical Study on the Effectiveness and Efficiency of Different Explainer Video Formats. Journal of Education and Learning, 6(1), 254-266.

Laaser, W., \& Toloza, E. A. (2017). The changing role of the educational video in higher distance education. The International Review of Research in Open and Distributed Learning, 18(2), 264276.

Lase, D. (2019). Education and Industrial Revolution 4.0. Jurnal Handayani, 10(1), 48-62.

Rafidiyah, D., \& Thania, M. (2018). Video-Based Instruction to Boost Students' Presentation Skill. Teaching English as Foreign Language and Applied Linguistic Journal, 1(1), 11-17.

Schwab, K. (2016). The Fourth Industrial Revolution: what it means, how to respond. Retrieved June 12， 2020, from World Economic Forum: https://www.weforum.org/agenda/ 2016/01/the-fourth-industrialrevolution-what-it-means-andhow-to-respond/

Shahroom, A. A., \& Hussin, N. (2018). Industrial Revolution 4.0 and Education. International Journal of Academic Research in Business and Social Sciences, 8(9), 314319. 